\title{
A Contemporary Narration on Presence of Cluster Bearing Trait in Juglans regia L. in Indian Himalayan Region
}

\author{
Lal Chand $^{1^{*}}$, D.B. Singh ${ }^{2}$, W.H. Raja ${ }^{2}$, K.L. Kumawat ${ }^{2}$, K.M. Rai ${ }^{3}$, \\ Iqra Qureshi ${ }^{2}$, Pawan Saini ${ }^{4}$ and Asha Ram ${ }^{1}$
}

${ }^{1}$ ICAR-Central Agroforestry Research Institute, Jhansi-284003, Uttar Pradesh, India

${ }^{2}$ ICAR-Central Institute of Temperate Horticulture, Srinagar-190007, Jammu \& Kashmir, India

${ }^{3}$ ICAR-National Bureau of Plant Genetic Resources Regional Station, Bhowali- 263132

(Nainital), Uttarakhand, India

${ }^{4}$ CSB-Central Sericultural Research and Training Institute, Pampore-192121, Jammu \& Kashmir, India

*Corresponding author

\section{A B S T R A C T}

\begin{tabular}{|c|c|}
\hline Keywords & $\begin{array}{l}\text { Persian walnut belongs to genus Juglans of family Juglandaceae and valued for its } \\
\text { nutritious kernels. The Persian walnut (Juglans regia } \text { L.) bear fruit in panicle of } 1 \text { to } 3\end{array}$ \\
\hline $\begin{array}{l}\text { Juglans regia, Bearing } \\
\text { habit, Cluster bearing, } \\
\text { Fruits per cluster, } \\
\text { Genotype }\end{array}$ & $\begin{array}{l}\text { fruits and occasionally with five fruits per panicle. Previous report showed that cluster } \\
\text { bearing is a rare trait in } J \text {. regia. A selective survey was conducted with the objective to } \\
\text { identify cluster bearing walnut genotypes and an intensive survey was done in four village }\end{array}$ \\
\hline Article Info & idia) during 2015-16. As a result, one cluster bearing \\
\hline $\begin{array}{l}\text { Accepted: } \\
30 \text { March } 2018 \\
\text { Available Online: } \\
10 \text { April } 2018\end{array}$ & $\begin{array}{l}\text { per terminal having approximately } 40-50 \text { percent frequency of clusters of } 10 \text { fruits. } \\
\text { However, maximum terminals were observed with } 2-10 \text { fruits per cluster. In this genotype, } \\
\text { mean nut weight, kernel weight and kernel recovery were recorded } 13.11 \mathrm{~g}, 6.16 \mathrm{~g} \text { and } \\
46.24 \% \text {, respectively. }\end{array}$ \\
\hline
\end{tabular}

\section{Introduction}

Among the temperate fruits, nut crops particularly walnut (Juglans spp.) has great scope to satisfy diversified needs of the farming community. Walnut was revered since ancient times as a symbol of intellectual, since their kernels have convoluted surface inside the shell resembling as that of brain. Its wood considered as best for making furniture and other purposes like interior decoration, panelling and flooring of houses. Walnut shells are also used to burn in the famous Kangree (traditional fire pot) for heating the room by hill community of the region. Walnut is valued and appreciated for its nutritious kernels which contain $64.5 \%$ fats, $15.6 \%$ protein, $10.6 \%$ carbohydrates and 687 calories of energy per $100 \mathrm{~g}$ (Singh et al., 1967). Its bark, leaves and hull are used 
traditionally for staining the gums and lips by the ladies of the region. Immature fruits are also used for preparation of delicious chutney.

It is a (walnut) perennial plant which belongs to Juglandaceae family, order fagales and is a diploid species $(2 n=32)$. Depending upon the sex expression, walnut exhibits bothmonocious and hetero-dichogamous habit (Gleeson, 1982), where mostly ( 80\%) protandrous type, a small number $(\sim 12 \%)$ is protogynous type and only a few $(\sim 8 \%)$ can be found as homogamous. It has been propagated through seed from centuries, which resulted in a heterogeneous population because of outbreeding (Cerovic et al., 2010). Climatic variations and evolutionary pressures further influence the geographic distribution and evolution of its new species. At present, about 21 species of Juglans were noticed and among these, Juglans regia L. was reported to be most economically and commercially exploited species. Vavilov considered Central Asia to be the primary center of origin where probably walnut domesticated (Vavilov, 1931).

It is native to region stretching from the Balkans eastward to the Western Himalayan (Fernandez-Lopez et al., 2000). NorthWestern Himalayan region of India is gifted with very rich diversity of walnut with high morpho-genetic variability. In India, Persian walnut is mainly grown in Jammu \& Kashmir, Uttarakhand, Himachal Pradesh, and minor production is also comes from North-Eastern Himalayas. The agro-climatic conditions of Jammu \& Kashmir (from an altitude of $\sim 900 \mathrm{~m}$ amsl in Rajouri and Kathua districts to $\sim 3150 \mathrm{~m}$ amsl in Leh and Kargil districts) are ideally suited for walnut growth and production. Some of the trees in Jammu and Kashmir are reported several centuries old and its long cultivation history has also resulted in the evolution of wider morpho-genetic variability in walnut varieties.
The tree canopy architecture is characterized by the two important morphological traits i.e. branching nature and fruiting / bearing habit. Usually branching habit in walnut is proleptic and develops from winter buds (Wu and Hinckley, 2001) and male and female flowers are borne at different location on the same tree. Male flower develop laterally from simple buds on 1-year-old wood while female flowers develop generally in panicle of 1-3 flowers from mixed buds in which flowering take place at terminal position of current season's leafy shoot irrespective of the bearing habit. Branching density and position of flowering buds on annual shoots is directly associated with fruit bearing habit of walnut crop (Germain, 1990 and 1992).

Worldwide, most of the Persian walnut $(J$. regia L.) varieties had been found with 1-3 fruits per panicle and occasionally with five nuts per panicle (Thakur 1993, Sharma and Sharma 1998aand McGranahan and Leslie, 2009).The cluster bearing trait (in which flowers borne in cluster on long raceme) had been reported in some species of Juglans viz. $J$. cinerea L., $J$. ailantifolia Carr., $J$. mandshurica Maxim (McGranahan and Leslie, 2009. Although, very few reports from different walnut growing countries was evidencing the cluster bearing habitin J. regia L. (Zarubin, 1954; Duskabilov, 1983; Xi, 1985; Reid, 1987; Thompson, 1993; Akca et al., 2001, Sutyemez and Caglar, 2001, Simsek et al., 2010 and Cerovic et al., 2010). As concerns in India, the cluster type bearing has nevertheless been revelled, interestingly in this study it is being recorded as in J. regia. Cluster bearing trait serves potential role for higher yieldin walnut improvement.There are possibilities to develop / evolve new genotypes with cluster bearing habit and other important agronomic traits. Hence, in the light of above facts and views, a target specific survey was conducted with the objective to identify cluster bearing walnut genotypes. 


\section{Materials and Methods}

An intensive survey was done in four village viz., Dadom Pora, Nowhar, Hanjum, Shum Nag of Budgam district of Jammu \& Kashmir (India). The survey area located at an altitude ranging between 1820 to $1960 \mathrm{~m}$ above mean sea level. Natural stand of approximately 2000 trees (500 trees in each village) on isolated hillocks of these four villages wereobserved for cluster bearing traits. First expedition was made during June, 2016 to see the bearing habit of natural walnut stands and second expedition was made during October (appropriate time for walnut fruit collection), 2016 at fruit maturity.

The morphological traits of walnut trees were recorded as per descriptor for walnut (IPGRI, 1994). Tree characteristics viz., tree growth habit, tree height and trunk circumference at base and at breast height, branching density, bearing habit, fruits per cluster, hull dehiscence were recorded. Fifteen leaves were collected during first expedition from selected tree and leaf characteristics (leaf type, number of leaflet, leaflet arrangement, leaflet shape, leaflet margin, leaflet apex shape and base shape, petiole length of compound leaf, length and width of compound leaf, middle leaflet and terminal leaflet) were recorded in laboratory of ICAR-Central Institute of Temperate Horticulture, Srinagar (ICARCITH). Nut samples were collected during second expedition and after sun drying, fifteen nuts were taken randomly for shell characteristics (texture, colour, seal, strength, integrity), nut characteristics (shape, weight, length, diameter, thickness, shell thickness) and kernel characteristics (weight, recovery, colour, fill and plumpness).

\section{Results and Discussion}

In survey area, most of the trees were found with terminal bearing habit (fruits on terminal position of leafy shoots which arises from terminal bud of 1-year-old shoots). During survey visit, four trees which were given some direction towards trait of interest were tagged from different villages of Budgam district and named as DP-1 (from village Dadom Pora), NW-1 (from village Nowhar), HJ-1 (from village Hanjum) and SN-1 (from village Shum Nag).

DP-1 was having up to 5 fruits per panicle but only few terminals with five fruits and trees having spreading growth habit were found (Figure 1A). NW-1 was identified from village Nowhar which again having up to five fruits per terminal but very few terminals with five fruits. Tree having upright growth habit with sparse branching (Figure 1B).

Similar results with respect to bearing habit, growth type and number of fruits per panicle was reported by Thakur (1993) and Sharma and Sharma (1998a) where trees bearing 5 or less than 5 fruits per panicle having spreading, semi-spreading, semi-erect and erect type of tree growth. Intermediate bearing habit which is another promising trait for walnut improvement reported from Hanjum village in HJ-1 (Figure 1C). Only few trees were found with intermediate bearing habit in which fruits were borne on both terminal and sub terminal buds of 1-year-old shoots. Similar intermediate bearing habit along with terminal and lateral bearing had also been reported by Aleta and Ninot (1997) from Mediterranean and Atlantic Spanish Coast.

Only one tree $(\mathrm{SN}-1)$ was identified with cluster bearing trait from village Shumnag on which, fruits were borne on terminal long stalk arising on leafy shoots and having up to 10 fruits per cluster (approximately $40-50 \%$ of a cluster of 10 fruits) (Figure 1D). Remaining terminals were having fruits in cluster with varying number ranging between 2-10 fruits per cluster. 
Table.1 Tree and leaf characteristics of cluster bearing genotype (SN-1)

\begin{tabular}{|c|c|c|c|}
\hline Trait & Value & Trait & Value \\
\hline Tree growth habit & Semi-upright & Leaflet shape & Elliptical \\
\hline Tree height & $\begin{array}{l}\text { Approx. } 12-13 \\
\mathrm{~m}\end{array}$ & Leaflet margin & Entire \\
\hline $\begin{array}{l}\text { Trunk circumference at } \\
\text { basal portion }\end{array}$ & $105 \mathrm{~cm}$ & Leaflet apex shape & Obtuse \\
\hline $\begin{array}{l}\text { Trunk circumference at } \\
\text { breast height }\end{array}$ & $89 \mathrm{~cm}$ & leaflet base shape & Obtuse \\
\hline Branching density & Intermediate & $\begin{array}{l}\text { Compound leaf: petiole } \\
\text { length }(\mathrm{cm})\end{array}$ & 9.31 \\
\hline Bearing & $\begin{array}{l}\text { Terminal in } \\
\text { cluster }\end{array}$ & Compound leaf: length & $38.20 \mathrm{~cm}$ \\
\hline $\begin{array}{l}\text { Number of fruit per } \\
\text { cluster }\end{array}$ & $1-10$ & Compound leaf: width & $22.87 \mathrm{~cm}$ \\
\hline Hull dehiscence & Dehiscent & Terminal leaflet: Length & $19.40 \mathrm{~cm}$ \\
\hline Leaf type & $\begin{array}{l}\text { Pinnately } \\
\text { compound }\end{array}$ & Terminal leaflet: Width & $12.43 \mathrm{~cm}$ \\
\hline Number of leaflet & $5-7$ & Middle leaflet: length & $14.90 \mathrm{~cm}$ \\
\hline Leaflet arrangement & Opposite & Middle leaflet: width & $6.68 \mathrm{~cm}$ \\
\hline
\end{tabular}

Table.2 Nut and kernel characteristics of cluster bearing genotype (SN-1) (mean of 15 nuts)

\begin{tabular}{|l|l|l|l|}
\hline Trait & Value/state & Trait & Value/state \\
\hline Nut shape & Short trapezoid & Nut length $(\mathbf{m m})$ & 36.19 \\
\hline Shell texture & Medium & Nut diameter $(\mathbf{m m})$ & 29.92 \\
\hline Shell colour & Light & Nut thickness $(\mathbf{m m})$ & 31.80 \\
\hline Shell strength & Strong & Shell thickness $(\mathbf{m m})$ & 2.18 \\
\hline Shell integrity & Complete & Kernel recovery $(\%)$ & 46.24 \\
\hline Shell seal & Strong & Kernel fill & Moderate \\
\hline Nut weight $(\mathbf{g})$ & 13.11 & Ease in removal of kernel halves & Moderate \\
\hline Kernel weight $(\mathbf{g})$ & 6.06 & Kernel colour & Light
\end{tabular}




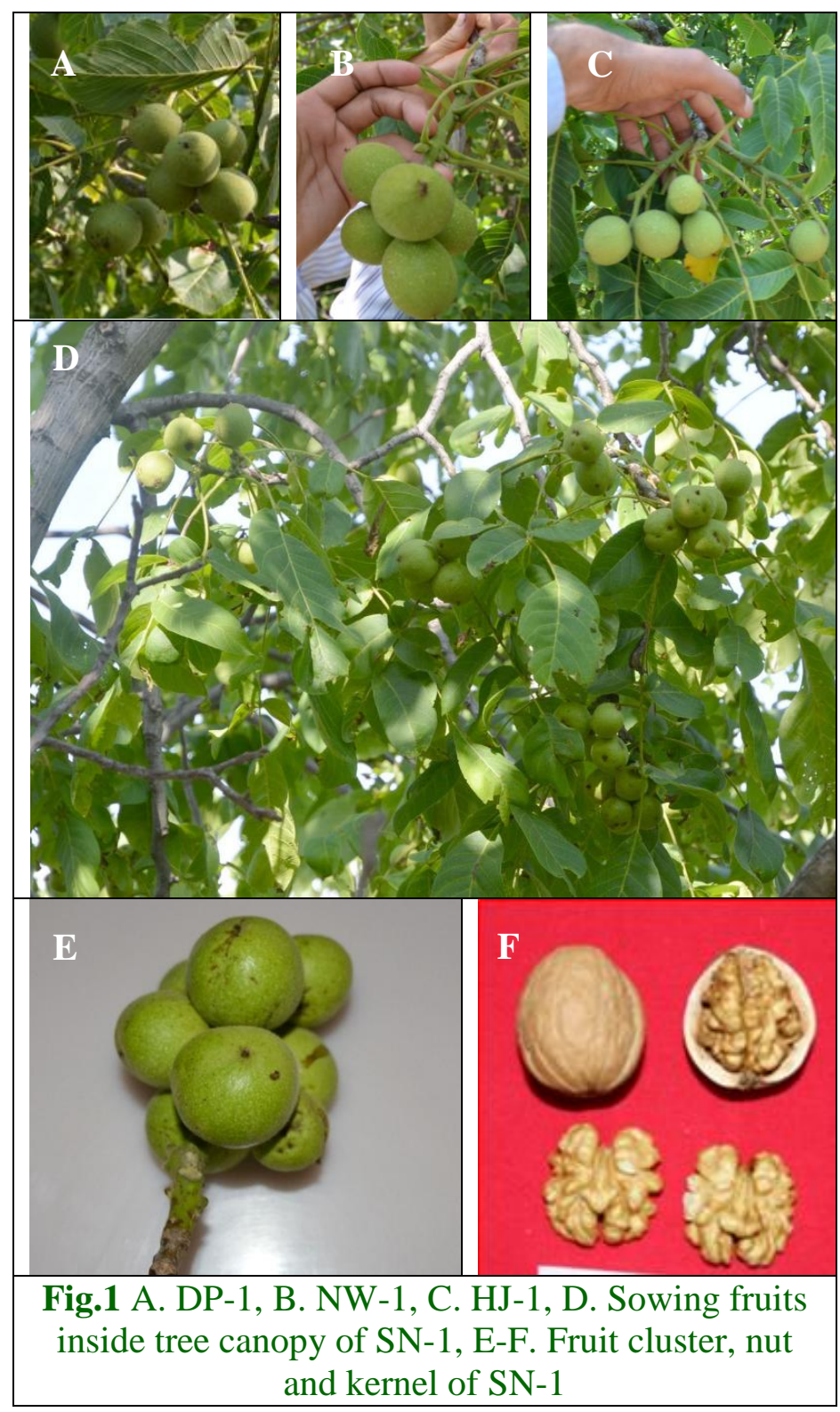

Similar results on were reported by Xi (1985) in Chinaand found that there are certain types in which nuts are borne in clusters. In these types 10 fruits per cluster with a frequency of occurrence of such characters may be upto 50 per cent have been recorded and that the trees are small and do not need pruning. Sutyemez et al., (1999) from the Bolu and Kahramanmaras province of Turkey found multiple fruited trees which given up to 20 nuts per cluster. Cerovic et al., (2010) reported cluster bearing from Serbia and accepted as racemose type of fruit bearing.
Sutyemez and Caglar (2001) reported number of fruits ranging 3 to 26 on a cluster in Turkish walnut. Similar types of report has been obtained by Zarubin (1954) from Kirghizia, Duskabilov (1983) from Tadjikistan, Reid (1987) from Yugoslavia, Thompson (1993) from Soviet Union and Simsek et al., (2010) from Turkey.

The mean nut weight, kernel weight and kernel recovery of $\mathrm{SN}-1$ was recorded $13.11 \mathrm{~g}$, $6.16 \mathrm{~g}$ and $46.24 \%$ respectively, with medium texture, light shell colour, strong seal and 
strength, complete shell integrity, short trapezoid shape with other nut and kernel characteristics (Table 1 and Figure 1E-F). Similarly, from Kahramanmaras province of Turkey, Sutyemez and Cagler (2001) reported genotypes with 26 fruits per cluster having nut weight $8.02 \mathrm{~g}$, kernel weight $5.36 \mathrm{~g}$ and kernel recovery $66.83 \%$ and from Bolu province was reported genotypes with 12 nuts per cluster having nut weight, kernel weight and kernel recovery of $11.0 \mathrm{~g}, 5.15 \mathrm{~g}$ and $46.81 \%$ respectively. Cerovic et al., (2010) have also been recorded nut weight up to 15.5 $\mathrm{g}$ and kernel recovery up to $51.2 \%$ in Tisa with 8 fruits per cluster. The tree growth habit is visually found to be semi-erect with intermediate branching and density, pinnate compound leaf and elliptical leaflet. Rouskas et al., (1997), Vesilescu and Botu (1997) and Solar and Stamper (2006) had also reported semi-erect type of growth habit. Thakur (1993) and Shilpa (2014) were observed elliptical shape of leaflet in J. regia.

Although, cluster was compact in $\mathrm{SN}-1$ and incidence of anthracnose was found in the tree. There are chances of availability of cluster bearing genotypes in walnut growing region of India which bear fruits loosely arranged on long stalk which may reduce chances of anthracnose. The higher number of fruit per cluster can be one of the important components in walnut productivity. Seedling size and precocity are very important trait interlinked with the vigour and height of walnut tree. Short sizes of seedlings are reported with low vigour and cluster bearing families by Rezaee et al., (2006). Cluster bearing have dwarfing effect on scion which reduced the length of internodes of the scion shoots and increased formation of lateral shoot which is also an important trait (Mahmoudi, 2011) (Table 2).

This study was carried out to identify the cluster bearing trait in walnut in North-West
Himalayan Region of India. The results have implication in identifying cluster bearing genotypes (SN-1) of J. regia, had higher fruit yield with superior yield attributes like mean nut weight, kernel weight and kernel recovery. Further exhaustive investigations are needed to evaluate such type of walnut genotypes on different aspect of tree vigor, growth habit, yield consistency and possibility of dwarfing nature. Besides this, it will also helpful in conservation of the diverse genetic resources and its genetic improvement for higher yield.

\section{Acknowledgements}

Research was carried out with the financial assistance from Department of Science and Technology, Government of India (Grant number DST/SPLICE/CCP/NMSHE/TF6/ICAR/2014 dated 16.03.2015) in the form of project "National Mission for Sustaining Himalayan Ecosystem-Task Force-6 (Himalayan Agriculture)".

\section{References}

Akca, Y., Keskin, S. and Celep, C. 2001. A study on the selection of superior walnut types with lateral bud fruitfulness and maximum of nuts per cluster. Acta Horti., 544, 125-128.

Aleta, N. and Ninot, A. 1997. Field evaluation of Juglans regia L. selected clones from the seedling populations of Mediterranean and Atlantic Spanish coast. Acta Horti., 442, 63-67.

Cerovic, S., Golosin, B., Todorovic, N. J., Bijelic, S. and Ognjanov, V. 2010. Walnut (Juglans regia L.) selection in Serbia. Hort. Sci., 37 (1), 1-5.

Duskabilov, T. 1983. Groups of varietal types of the Tadjikistan population of Juglans regia. Nauchno-tekhnicheslii Byulleten' Vsesoyuznogo Ordena Lenina I Ordena Druzhby Narodov Nauchno- 
Issledovatel'skogo

Institute

Rastenievodstva Ineni N. I. Vavilova $128,78-79$.

Fernandez-Lopez, J., Aleta, N. and Alias, R. 2000. Forest genetic resources conservation of Juglans regia L. IPGRI Publishers, Rome, Italy. pp. 20-25.

Germain, E. 1990. Inheritance of late leafing and lateral bud fruitfulness in walnut (Juglans regia L.), phenotypic correlations among some traits of the trees. Acta Horti., 284, 125-134.

Germain, E. 1992. Le noyer. In: Gallais A, Bannerot $\mathrm{H}$, eds. AmeÂlorationdes especesve ÂgeÂtalescultiveÂes, objectifs et criteÁres de seÂlection. Paris: INRA, 125-134.

Gleeson, S.K. 1982. Heterodichogamy in walnuts: Inheritance and stable ratios. Evol., 36 (5), 892-902.

IPGRI, 1994. Descriptors for walnut (Juglans spp.). International Plant Genetic Resources Institute, Rome, Italy.

Mahmoudi, M.J. 2011. Effect of early mature walnut genotypes rootstock on dwarfing of scion. M.Sc. Thesis, University of Tehran, Iran.

McGranahan, G. and Leslie, C. 2009. Breeding Walnuts (Juglans Regia). In: Breeding Plantation Tree Crops: Temperate Species. Eds. Mohan Jain, S. and Priyadarshan, P.M., Springer Publication. pp. 249-274.

Reid, W. 1987. Persian walnuts in Yugoslavia. Ann. Rept Northern Nut Growers Assn., 78: 159-164.

Rezaee, R., Grigoorian, W., Vahdati, K. and Valizadeh, M. 2006. Evaluation of morphological traits associated with the vigour of Persian walnut (Juglans regia L.) seedlings. Iran. J. Hort. Sci. Technol., 7, 157-168.

Rouskas, D., Katranis, N., Zakynthinos, G. and Isaakidis, R. 1997. Walnut (Juglans regia L.) seedling selection in Greece. Acta Horti., 442, 109-116.
Sharma, S.D. and Sharma, O.C. 1998a. Variation for tree, foliage and floral characters in walnut seedling origin trees (Juglans regia L.) as influenced by their age. J. Hill Res., 11(1), 53-56.

Shilpa, 2014. Evaluation and characterization of walnut germplasm. M.Sc. Thesis. Dr. Y. S. Parmer University of Horticulture and Forestry, Solan, H.P., India. pp. 1154.

Simsek, M., Yilmaz, K.U. and Demirkiran, A.R. 2010. Selection and determination of some significant properties of superior walnut genotypes. Scientific Research and Essays, 5(19), 29872996.

Singh, S., Krishnamurthy, S. and Katyal, S.L. 1967. Fruit culture in India. ICAR Publication. pp. 7-8.

Solar, A. and Stampar, D. 2006. Evaluation of some perspective walnut genotypes in Slovenia. Acta Horti., 705, 131-136.

Sutyemez, M. and Caglar, S. 2001. Distribution of some morphological traits in walnut seedling trees. FAOCIHEAM-Nucis-Newsletter, 10, 20-21.

Sutyemez, M., Kaska, N. and Eti, S. 1999. Multiple fruited walnuts in Kahramanmaeas and Bolu, Turkey. Acta Horti., 544, 37-45.

Thakur, D. 1993. Genetic variability in bearing seedling walnuts (Juglans regia L.) in Kullu valley. M.Sc. Thesis, Dr. Y. S. Parmar University of Horticulture and Forestry, Solan, H.P., India.

Thompson, M.M. 1993. Exploration and exploitation of new fruit and nut germplasm. In: J.Janick and J.E. Simon (eds.), New crops. Wiley, New York. pp. $155-160$.

Vasilescu, Victor N. and Botu, M. (1997). The principal varieties of walnut from Romania. Acta Hortic. 442, 271-276.

Vavilov, N.I. 1931. The wild relatives of fruit trees of the Asian part of the USSR and Caucasus and problems of origin of fruit 
trees. Tr. Po. Prikl. Bot. Genet. i sel.,26, 343-360 (In Russian).

Wu, R.L. and Hinckley, T.M. 2001. Phenotypic plasticity of sylleptic branching: genetic design of tree architecture. Critical Rev. Plant Sci., 20, 467-485.

Xi, S.K. 1985. Walnut research and production in China. Annual report of the Northern Nut Growers Association, 76, 131-134.

Zarubin, A. F. 1968. Reclamation and development of walnut and fruit forests in southern Kirghizia: (Vosstanovlenie i razvitie orekhovo-plodovykh lesov yuzhnoi Kirghizii). Israel Program for Scientific Translations, Jerusalem, 4, 104. Translated from Russian [by Raya Karschon].

\section{How to cite this article:}

Lal Chand, D.B. Singh, W.H. Raja, K.L. Kumawat, K.M. Rai, Iqra Qureshi, Pawan Saini and Asha Ram. 2018. A Contemporary Narration on Presence of Cluster Bearing Trait in Juglans regia L. in Indian Himalayan Region. Int.J.Curr.Microbiol.App.Sci. 7(04): 3827-3834.

doi: https://doi.org/10.20546/ijcmas.2018.704.430 